\title{
Social-economic development of the United Territorial Communities and development of a strategy for sustainable development (case of Ukraine)
}

\author{
DENYS TARASENKO ${ }^{1}$, OLENA TSYKLAURI ${ }^{2}$, SVITLANA BELEI $^{3}$, MARYNA RIABENKA $^{4}$, \\ IRYNA MAZURKEVYCH ${ }^{5}$, SERHII BASHLAI ${ }^{6}$
}

\author{
${ }^{1}$ Public Administration and Governance Department, Donetsk State University of Management, \\ UKRAINE \\ ${ }^{2}$ Special Legal Disciplines Department, Donetsk State University of Management, UKRAINE \\ ${ }^{3}$ Department of Accounting and Taxation, Chernivtsi National University, UKRAINE \\ ${ }^{4}$ Department of Tourism, Hotel and Restaurant Business, Vinnytsia Institute of Trade and Economics \\ of Kyiv National University of Trade and Economics, UKRAINE \\ ${ }^{5}$ Department of Tourism, Hotel and Restaurant Business, Vinnytsia Institute of Trade and Economics \\ of Kyiv National University of Trade and Economics, UKRAINE \\ ${ }^{6}$ Department of Economics and Entrepreneurship, Sumy National Agrarian University, UKRAINE
}

\begin{abstract}
The unification of territorial communities allows forming an effective and convenient system of management of the territory in which they live. However, the unification of territorial communities in Ukraine is uneven, which raises the question of why this is happening. The purpose of the study is to analyze the level of social-economic development of united territorial communities in Ukraine and the choice of sustainable development strategies (adaptation, innovation, anti-crisis) for UTCs of different levels, identify problems of social-economic development and outline areas to address them. Research methods: generalization and scientific abstraction; system-structural and comparative analysis; economic and mathematical modeling; clustering. It has been established that the unification of different territories in Ukraine took place unevenly (with different levels of social-economic development). The study found that the unification of different territories in Ukraine took place unevenly due to different levels of their socio-economic development. It has been established that throughout Ukraine, communities with a low and high level of development predominate and to a lesser extent with a medium level of development. According to the results of the analysis, territorial communities were grouped into 3 regional clusters: cluster 1 - UTCs and territories with a high level of socialeconomic development (Kyiv and 9 regions); cluster 2 - UTCs and territories with an average level of socialeconomic development (6 regions); cluster 3 - UTCs and territories with a low level of social-economic development (10 regions). It has been proved that the social-economic development of UTCs is ensured by the improvement of financial, innovative, and investment activities of enterprises operating in communities. It has been proposed to apply an adaptation strategy of sustainable development for the territories of cluster 1; for cluster 2 - innovative strategy of sustainable development; for cluster 3 - anti-crisis strategy of sustainable development. Continuation of research in terms of determining the impact of enterprises on the socio-economic development of UTCs is promising not only in scientific terms but also to address the applied problems of developing a strategy for sustainable development at the level of individual UTCs in Ukraine. The studied methodology for the unification of territorial communities can be used to predict the further formation of UTCs in Ukraine and can be applied for territorial and administrative reforms in countries with uneven regional development.
\end{abstract}

Key-Words: - Territorial Community (Commune, Community), United Territorial Communities (UTCs), Indicators of Social-economic Development, Welfare, Sustainable Development Strategy

Received: October 24, 2020. Revised: February 28, 2021. Accepted: March 12, 2021. Published: March 26, 2021. 


\section{Introduction}

Satisfaction of social needs is an important condition for ensuring the livelihood of everyone. As noted by Lieberman [1], "socially connected will be a lifelong need, like food and warmth". To meet the most important individual and social needs, social institutions are created and formed, which are regulatory mechanisms in all major spheres of human life. Institutions ensure the stability and predictability of human relations and behavior, protect the rights and freedoms of citizens, protect society from disorganization, and form a social system and more. Forasmuch as the vast majority of their social needs are met in the place where they live (villages, settlements, cities), a territorial community is such important institution.

The community is a vital dimension in modern society and a key element of social organization. The creation of a united territorial community (UTC) is the formation of an effective and convenient system of territory management for its residents. Such a system is based primarily on the transfer of resources, powers and responsibilities from the central government to the local level. The association of individual communities enables their residents to receive educational, medical and administrative services, roads, lighting, water supply, garbage, landscaping, construction, etc. in their territories. Residents of united communities have the right to elect the government and have the leverage to influence it, which creates conditions for improving the quality of services, creating favorable living conditions.

The united territorial community is a prerequisite for their social-economic development, but does not automatically make their activities effective. First of all, it is necessary to increase revenues and develop the economic potential of communities, which requires the development of strategies for their development. The association of territorial communities makes it possible to form an effective and convenient system of management for residents of the territory in which they live. However, the unification of territorial communities in Ukraine is carried out unevenly, which raises the question of why this is happening.

The purpose of the study is to analyze the level of social-economic development of united territorial communities in Ukraine and the choice of sustainable development strategies (adaptation, innovation, anti-crisis) for UTCs of different levels, identify problems of social-economic development and outline areas to address them.
Research objectives of the scientific article are as follows:

- to carry out analysis of the distribution of UTCs in Ukraine and determination of the factors of such distribution;

- to carry analysis of social-economic indicators of the regions that include UTCs;

- to determine the interconnection between social and economic development of UTCs and the results of enterprises' activities in the territories in which they are located;

- to form regional clusters with different levels of social-economic development of territories, namely: the first cluster - UTCs and territories with a high level of social-economic development; the second cluster - UTCs and territories with an average level of socialeconomic development; the third cluster UTCs and territories with a low level of socialeconomic development;

- substantiate proposals for choosing a sustainable development strategy for regional clusters.

\section{Literature Review}

There is no agreed definition of the territorial community concept among scientists and researchers. Consequently, some scientists in their works raise debatable issues regarding the formation of the conceptual and categorical apparatus of this definition [2-5]. This concept is often used as a substitute term for locality; however, "community", according to Douglas, exists outside of physical places [2]. Brint suggests that community members are connected primarily through common personal interests. He has defined communities as a group of people who share common activities and who are connected mainly by common values and concerns [3].

However, the territory still forms the basis of communities. Thus, Hillery has identified elements that characterize the community as, first of all, a geographical area, and then kinship, self-sufficiency (separation), general lifestyle and type of social interactions [4]. Brown, Perkins \& Brown believe that joining the community brings benefits and improves well-being [5].

The above mentioned necessitates the assessment of social-economic development of communities. Zyzda, Bilous, Pronko et al. made assessment of the functioning of territorial communities according to various indicators [6-9]. Consequently, Bilous notes that "in the process of selecting indicators for 
assessing the social-economic development of UTC, one should pay attention on those indicators that reflect the focus on ensuring equal opportunities and accessibility of technological progress, not only within different social segments of the population, but also in different geographical regions". In the scholar's viewpoint, these criteria are most consistent with indicators of an inclusive nature [7]. Popova \& Demchenko have proven that the main indicators of social-economic development of UTCs are as follows: their area, demographic structure of the population, income and expenditure, funding structure, structure of economic entities by types of activity and income level, number of social infrastructure facilities, employment and unemployment in communities [10].

Tymochenko \& Simakhova have investigated the theoretical and methodological foundations of regional social-economic development. According to their viewpoint, development is not a simple change, but only the one that presupposes a new quality. Scientists emphasize that "in the context of the processes that outline the category of "development", two permanent directions of movement to a qualitatively new state can be outlined, namely: social and economic ones". By the way, in order to assess the social-economic development of individual regions, not just data on communities' social-economic development is required, but only that part of the information that is isolated from the general array, according to certain criteria of suitability and content saturation [11].

The issues of the process of unification of territorial communities deserve special attention. Some researchers believe that the possibility of voluntary unification of communities poses a new problem - the emergence of "rich" and "poor" communities - that is, high-income communities will not show a desire to unite with the less prosperous ones. Donchenko has predicted three possible scenarios for the development of UTCs in Ukraine after 2020: inertial, voluntary and centralized. In the first and second cases, only communities with natural resource sites will benefit from centralization [12]. The unevenness of UTCs is also caused by the problem of establishing boundaries in the process of unification of territorial communities. Consequently, Dorosh, Kupriyanchyk \& Dorosh have found significant differences between the area of village councils, which are part of the Ukrainian UTCs and settlements [13].

However, as it has been noted by Evtushenko \& Lushahina, the area of UTC and the number of communities that are part of it do not determine the effective social-economic development of UTC.
According to the results of the study, scientists have identified indicators of successful social-economic development of UTC. These indicators are as follows: human resources; strategic planning, that is, vision of specific ways of development of the territorial community; local identity; ability to attract "donor" funds; the ability of the community to rationally use available resources [14]. Some relevant studies can be found in [15] and [16].

Taking into consideration the potential and availability of resources at the disposal of the community, as it has been emphasized by Palchuk, a strategic plan for the development of UTC should be drawn up, which, in turn, should meet the wishes and needs of the community [17]. Tolubyak \& Kostetskyy believe, that providing territorial communities, on the one hand, with the maximum number of resources and powers, and on the other increased responsibility, will allow UTC to become new points of social-economic growth in the country. The positive results of the activities of more UTCs, in their opinion, are a confirmation of the correctness of such a development strategy [18].

The issues of the interrelationship between the investment activity of enterprises and the socialeconomic development of territorial communities deserve special attention in the works of Buleev et al. [19]. According to the results of the rating assessment of Ukrainian enterprises, scientists have identified the regions that are characterized by the highest, medium and low investment activities, for each of which a sustainable development strategy has been proposed. Herewith, Kvon et al., assign an important role to investment policy at the regional level for the effective implementation of such a strategy [20].

A review of literature sources has made it possible to identify the problems of UTCs of Ukraine at two levels: at the general level -the unevenness of UTC unifications; at the level of individual UTCs - a low level of their socialeconomic development.

\section{Materials and methods of the research}

In the process of research, both general scientific and specific methods are applied: logical generalization and comparison - to substantiate the theoretical basis and research and formulation of basic hypotheses on the development of territorial communities in terms of sustainable development; induction and deduction, generalization and scientific abstraction - to determine the essence of the concept of "community" and "territorial 
community" and justify their consideration from the viewpoint of the theory of collective actions; system-functional - in the generalization, analysis and synthesis of theoretical aspects of UTC's crowdfunding; analysis and synthesis, systemstructural and comparative analysis - in comparing UTC indicators of different regions of Ukraine; system and situational approach - for interpreting the results of the analysis.

In order to determine the relationship between the number of formed UTC, population density of communities and the number of united councils, regression analysis has been used, the results of which will predict the process of UTC formation taking into account the selected variables.

Correlation and matrix analysis have been used to determine the interrelationship between social and economic indicators of regional development. The obtained data have been investigated by applying rating analysis, the results of which have been used in order to build clusters of regional development of UTC.

The analysis was conducted in terms of 24 regions of Ukraine and the city of Kyiv. In the direction of allocation of the UTCs in Ukraine the indicators of 2020 have been used, in the direction of the analysis of social and economic indicators of the regions which include UTCs - indicators of 2019 have been applied.

The academic paper has analyzed:

- social-economic indicators reflected in Ukrstat (2019): Incomes of the population, UAH million; Expenditures of the population, UAH million; Disposable income of the population, UAH million; Disposable income per capita, UAH; Average salary, UAH; Employed population aged 15-70 years, thousand people; Number of migrants (arrivals); Capital investments, UAH million; Gross regional product, UAH million; Volume of sold products (goods, services) of enterprises, UAH million; Number of enterprises; Financial result prior taxation of large and medium-sized enterprises that made a profit, UAH million; Personnel costs of enterprises, UAH million;

- indicators of allocation of united territorial communities in Ukraine, reflected in Decentralization (2020): Number of UTCs, units; Number of local councils merged; Number of populations living on the territory of UTC; UTC territory, $\mathrm{km}^{2}$.

\section{Results}

The term "community" (commune, etc.) implies, first of all, the connection of certain people in one place according to their common interests. In this case, such a common interest is the territory in which they live. The question arises, how to implement different goals and interests of people in the same direction? The answer to this question can be found in the theory of collective action or the economic theory of clubs, the main essence of which boils down to the fact that people unite in teams when they cannot implement their interests alone $[21 ; 22]$. The essence of the "club economy" model is that it is easier for an individual to meet their social and economic needs and implement their interests in a group than individually. The creation of "clubs" (interest groups, associations, and communities) and the entry of individual economic entities are appropriate if the benefits they receive from the collective consumption of goods per member are higher than if the good has been consumed individually. By the same principle, not only people unite in separate communities, but also communities with other communities - when the resources at their disposal are not enough to get results, in this case - to ensure life and improve their quality of life of people living in the common area.

One of the problems that exists in Ukraine today is the uneven unification of territorial communities. Thus, as of September 2020, there are 982 united territorial communities in Ukraine in 24 regions, which are located in 476 areas (Table 1).

Table 1. United territorial communities in Ukraine: list and basic data

\begin{tabular}{|l|c|c|c|c|c|}
\hline \multicolumn{1}{|c|}{ Regions } & District* & $\begin{array}{c}\text { The number of local } \\
\text { councils that have } \\
\text { merged }\end{array}$ & $\begin{array}{c}\text { Number of } \\
\text { communities }\end{array}$ & Square, $\mathrm{km}^{2}$ & Population \\
\hline Cherkasy oblast & 20 & 222 & 57 & 8527,59 & 337088 \\
\hline Chernihiv oblast & 22 & 372 & 50 & 20570,16 & 502223 \\
\hline Chernivtsi oblast & 11 & 132 & 37 & 3879,71 & 359796 \\
\hline Dnipropetrovsk oblast & 22 & 229 & 71 & 21258,65 & 905157 \\
\hline Donetsk oblast & 18 & 74 & 13 & 5233,89 & 239356 \\
\hline Ivano-Frankivsk oblast & 14 & 176 & 39 & 4039,99 & 712658 \\
\hline Kharkiv oblast & 27 & 114 & 23 & 7588,37 & 375753 \\
\hline Kherson oblast & 18 & 115 & 33 & 9665,54 & 275216 \\
\hline Khmelnytsky oblast & 20 & 370 & 51 & 12645,85 & 570433 \\
\hline
\end{tabular}




\begin{tabular}{|l|c|c|c|c|c|}
\hline Kirovohrad oblast & 21 & 81 & 27 & 6050,35 & 161543 \\
\hline Kyiv oblast & 25 & 142 & 24 & 5236,87 & 329803 \\
\hline Luhansk oblast & 18 & 75 & 18 & 7037,72 & 115084 \\
\hline Lviv oblast & 20 & 174 & 41 & 5082,88 & 352165 \\
\hline Mykolaiv oblast & 19 & 146 & 42 & 12600,01 & 318142 \\
\hline Odessa oblast & 26 & 158 & 37 & 11556 & 370960 \\
\hline Poltava oblast & 25 & 195 & 53 & 10051,4 & 405878 \\
\hline Rivne oblast & 16 & 148 & 45 & 7874,42 & 354599 \\
\hline Sumy oblast & 18 & 187 & 38 & 10376,2 & 757042 \\
\hline Ternopil oblast & 17 & 314 & 54 & 6800,94 & 671976 \\
\hline Vinnytsia oblast & 27 & 156 & 46 & 5570,2 & 752594 \\
\hline Volyn oblast & 16 & 235 & 54 & 11802,08 & 604561 \\
\hline Zakarpattia oblast & 13 & 61 & 17 & 1687,65 & 278194 \\
\hline Zaporizhzhia oblast & 20 & 199 & 56 & 18707,34 & 510738 \\
\hline Zhytomyr oblast & 23 & 412 & 56 & 19570,01 & 812814 \\
\hline Total in the Ukraine & $\mathbf{4 7 6}$ & $\mathbf{4 4 8 7}$ & $\mathbf{9 8 2}$ & $\mathbf{2 3 3 4 1 3 , 8}$ & $\mathbf{1 1 0 7 3 7 7 3}$ \\
\hline
\end{tabular}

* - without taking into account the areas of the temporarily occupied territories.

However, if we analyze the united territorial communities in more detail, we can see the unevenness of their formation - in some areas the number of UTCs exceeds fifty (Dnipropetrovsk, Cherkasy, Zhytomyr, Zaporizhia, Ternopil, Volyn, Poltava, Khmelnytsky), and in others it fluctuates at the level of ten to thirty (Donetsk, Zakarpattia, Lugansk, Kharkiv, Kyiv, Kirovograd).

The basic challenges faced by the world community are caused by: the lack of clear regulations and algorithms for overcoming the effects of viral infection in the context of combating corruption; lack of interaction, mutual control and mutual restraint between authorities and management, anti-corruption bodies, local authorities; disregarding the interests of the civil society, reducing the level of trust and understanding; imperfection of reporting mechanisms and transparency in the actions of anticorruption bodies and other authorities of national or local level; lack of integrity, openness and legality in the actions of higher authorities and some public officials [23].

Moreover, such a distribution is not always related to the area of the territories where the UTCs are located or the number of districts. Some of the UTCs created in some regions can be explained by the number of people living there. For example, in the UTCs' territories located in Donetsk, Kirovohrad and Luhansk oblasts, the population is 239 thousand, 162 thousand and 115 thousand people, respectively (Table 1), which is 4-8 times less than in Dnipropetrovsk oblast, on the territory of which there are 71 UTCs. However, how to explain the small number of united territorial communities in Kharkiv region, where 376 thousand people live, which is almost equal to Poltava region, where 406 thousand people live, however, the number of UTCs of Poltava region exceeds the number of UTCs of Kharkiv region in 2,4 times?

In order to determine the factors that affect the number of UTCs within one area, we will use the tools of correlation and regression analysis. The study was conducted using the MS Excel software package.

Taking into account the stages of mathematical modeling in economics [24], three structural elements will take part in the process of modeling the influence of factors on the number of UTCs within one region: object of research (UTC in Ukraine), subject (researcher); a model that mediates the interrelationship between a subject and an object. An indicator that characterizes the number of UTCs within one region (number of communities) was chosen as an endogenous (dependent) variable (Y). Factors influencing the number of UTCs within one area are selected based on data presented in official statistics (Decentralization, 2020).

Based on the results of the preliminary analysis on the presence of correlation and lack of multicollinearity between variables, the following exogenous (independent) variables have been selected, namely: x1 - the number of local councils that have merged regions (units); $\mathrm{x} 2$ - population density (number of persons per $1 \mathrm{~km}^{2}$ of the territory). The number of districts in the region was removed from the model due to the lack of correlation between the number of districts and the number of UTCs within one oblast $(\mathrm{R}=0,14)$ (Table 2). The indicators in Table 2 for further analysis were ranked in descending of the number of local councils that have merged. 
Table 2. Parameters of the regression equation*

\begin{tabular}{|c|c|c|c|}
\hline & Number of communities & $\begin{array}{c}\text { Number of local councils } \\
\text { that have merged }\end{array}$ & $\begin{array}{c}\text { Population } \\
\text { density }\end{array}$ \\
\hline & $Y_{1}$ & $x_{1}$ & $x_{2}$ \\
\hline Zhytomyr oblast & 56 & 412 & 41,53 \\
\hline Chernihiv oblast & 50 & 372 & 24,42 \\
\hline Khmelnytsky oblast & 51 & 370 & 45,11 \\
\hline Ternopil oblast & 54 & 314 & 98,81 \\
\hline Volyn oblast & 54 & 235 & 51,22 \\
\hline Dnipropetrovsk oblast & 71 & 229 & 42,58 \\
\hline Cherkasy oblast & 57 & 222 & 39,53 \\
\hline Zaporizhzhia oblast & 56 & 199 & 27,30 \\
\hline Poltava oblast & 53 & 195 & 40,38 \\
\hline Sumy oblast & 38 & 187 & 72,96 \\
\hline Ivano-Frankivsk oblast & 39 & 176 & 176,40 \\
\hline Lviv oblast & 41 & 174 & 69,28 \\
\hline Odessa oblast & 37 & 158 & 32,10 \\
\hline Vinnytsia oblast & 46 & 156 & 135,11 \\
\hline Rivne oblast & 45 & 148 & 45,03 \\
\hline Mykolaiv oblast & 42 & 146 & 25,25 \\
\hline Kyiv oblast & 24 & 142 & 62,98 \\
\hline Chernivtsi oblast & 37 & 132 & 92,74 \\
\hline Kherson oblast & 33 & 115 & 28,47 \\
\hline Kharkiv oblast & 23 & 114 & 49,52 \\
\hline Kirovohrad oblast & 27 & 81 & 26,70 \\
\hline Luhansk oblast & 18 & 75 & 16,35 \\
\hline Donetsk oblast & 13 & 74 & 45,73 \\
\hline Zakarpattia oblast & 17 & 61 & 164,84 \\
\hline
\end{tabular}

The multiple regression equation takes the following form:

$$
Y=b_{1} x_{1}+b_{2} x_{2}+c,
$$

where $\quad Y-$ endogenous (dependent) variable, resulting indicator; $b_{1}-b_{2}-$ coefficient that determines the degree of influence of the variable $X$ on the variable $Y$ (regression parameters); $x_{1}-x_{2}-$ exogenous (independent) variables.

Analysis of the model showed the following results. The variation of factor variables explains the variation of the dependent variable by at least $91 \%$ (multiple coefficient of determination R2 $=0,91$, which according to the Chaddock scale characterizes the interrelationship between performance and model factors as very high (close)); reliability level - 95\% (Table 3).
Table 3. Regression analysis result

\begin{tabular}{|c|c|c|c|}
\hline \multicolumn{2}{|c|}{ Regression statistics } & \multicolumn{2}{c|}{ Coefficients } \\
\hline Multiple R & 0,958452151 & Y-intersection & 0 \\
\hline R-square & 0,918630527 & Variable $X_{1}$ & 0,174632023 \\
\hline $\begin{array}{c}\text { Normalized } \\
\text { R-square }\end{array}$ & 0,869477369 & Variable $X_{2}$ & 0,093064923 \\
\hline Standard error & 12,94371452 & - & - \\
\hline Observations & 24 & - & - \\
\hline
\end{tabular}

As a result of modeling, a multiple regression equation is obtained, the economic content of which is as follows:

- joining one council to UTC leads to an increase in the number of UTCs within one oblast by 0,2 units, that is, an average of five councils is required to create one UTC within one oblast;

- increasing the population density in the united communities by 1 unit leads to an increase in the number of UTCs in this area by 0,1 units (in other words, to create 1 community it is necessary that the population per $1 \mathrm{~km}^{2}$ increased by 10 people).

$$
Y=0,174 x_{1}+0,093 x_{2}
$$

Regression analysis was used to establish the interrelationship between the variable and 
independent variables. This regression equation allows predicting the value of the number of UTC depending on the studied parameters.

The simulation results showed the following pattern: the lower the population density within one district is, the fewer councils are combined into one UTC. We can assume that the population density in these areas is determined by the level of socialeconomic development. Therefore, it is necessary to study the indicators of social-economic development of the territories where UTCs are located and to identify the level of their development.

Consequently, in Dnipropetrovsk, Kyiv, Lviv, Kharkiv, Donetsk, Odesa and Zaporizhia oblasts, incomes can be defined as high (UAH 353-167 billion per year), in Poltava, Vinnytsia, Cherkasy, Mykolaiv, Ivano-Frankivsk, Khmelnytsky and Zhytomyr regions - average incomes (UAH 130-92 billion per year), and Sumy, Kherson, Volyn, Chernihiv, Zakarpattia, Rivne, Kirovohrad, Ternopil, Chernivtsi and Luhansk regions are among the group of regions with the lowest incomes in Ukraine (UAH 91-58 billion per year).

The largest income gap is observed in the city of Kyiv. This indicator amounted to UAH 625 billion in 2019, which is on average three times higher than the revenues of the high-income regions' group, six times higher than the middle-income regions' group, and compared to the revenues of the low-income regions' group, the city of Kyiv is almost an order of magnitude higher (nine times higher) (Table 4).

Table 4. Social and economic indicators in the regions of Ukraine (in absolute terms)

\begin{tabular}{|l|c|c|c|c|c|c|}
\hline \multicolumn{1}{|c|}{$\begin{array}{l}\text { Regions **/ } \\
\text { Indicators }\end{array}$} & $\begin{array}{c}\text { Revenues, } \\
\text { UAH } \\
\text { million }\end{array}$ & $\begin{array}{c}\text { Disposable } \\
\text { income, } \\
\text { UAH } \\
\text { million }\end{array}$ & $\begin{array}{c}\text { Expendi } \\
\text { tures, } \\
\text { UAH } \\
\text { million }\end{array}$ & $\begin{array}{c}\text { Employed } \\
\text { population } \\
\text { aged 15-70 } \\
\text { years, } \\
\text { thousand } \\
\text { people }\end{array}$ & $\begin{array}{c}\text { Capital } \\
\text { investments, } \\
\text { UAH million }\end{array}$ & $\begin{array}{c}\text { Gross regional } \\
\text { product, UAH } \\
\text { million }\end{array}$ \\
\hline Vinnytsia oblast & 129787 & 100518 & 125432 & 660,7 & 15724,9 & 111498 \\
\hline Volyn oblast & 71537 & 54645 & 76494 & 380,0 & 12664,0 & 60448 \\
\hline $\begin{array}{l}\text { Dnipropetrovsk } \\
\text { oblast }\end{array}$ & 352532 & 278074 & 317005 & 1413,7 & 66951,1 & 369468 \\
\hline Donetsk oblast & 197830 & 162394 & 134396 & 747,2 & 30594,5 & 192256 \\
\hline Zhytomyr oblast & 96583 & 75233 & 102487 & 521,2 & 8466,9 & 77110 \\
\hline Zakarpattia oblast & 77568 & 59621 & 90351 & 508,9 & 9330,3 & 52445 \\
\hline Zaporizhzhia oblast & 166508 & 127935 & 168087 & 741,6 & 14876,7 & 147076 \\
\hline $\begin{array}{l}\text { Ivano-Frankivsk } \\
\text { oblast }\end{array}$ & 97919 & 76124 & 100991 & 575,1 & 9305,5 & 78443 \\
\hline Kyiv oblast & 171660 & 133347 & 209707 & 771,4 & 50295,7 & 198160 \\
\hline Kirovohrad oblast & 71726 & 54752 & 78358 & 384,5 & 7794,3 & 64436 \\
\hline Luhansk oblast & 65859 & 52477 & 48296 & 303,7 & 3357,5 & 35206 \\
\hline Lviv oblast & 216966 & 165350 & 238936 & 1075,2 & 31061,5 & 177243 \\
\hline Mykolaiv oblast & 91709 & 71678 & 91369 & 499,6 & 12549,3 & 79916 \\
\hline Odesa oblast & 221965 & 173188 & 256619 & 1020,1 & 21080,1 & 173241 \\
\hline Poltava oblast & 129922 & 99827 & 128788 & 591,2 & 23005,3 & 174147 \\
\hline Rivne oblast & 81307 & 62587 & 81924 & 486,0 & 6729,2 & 56842 \\
\hline Sumy oblast & 90518 & 70195 & 87771 & 490,9 & 7734,2 & 68489 \\
\hline Ternopil oblast & 68968 & 51951 & 73393 & 417,7 & 9210,3 & 49133 \\
\hline Kharkiv oblast & 246086 & 174779 & 316361 & 1263,9 & 22874,6 & 233321 \\
\hline Kherson oblast & 75701 & 58983 & 92494 & 455,3 & 12368,3 & 55161 \\
\hline Khmelnytsk oblast & 96886 & 73073 & 108661 & 528,8 & 10534,1 & 75646 \\
\hline Cherkasy oblast & 92974 & 70523 & 105042 & 531,8 & 11385,5 & 93315 \\
\hline Chernivtsi oblast & 57755 & 43574 & 76299 & 394,1 & 4096,8 & 33903 \\
\hline Chernihiv oblast & 76985 & 58816 & 82520 & 435,8 & 8740,5 & 70624 \\
\hline Kyiv & 652095 & 488412 & 623730 & 1379,9 & 213247,8 & 833069 \\
\hline Sorvin & & & & & \\
\hline
\end{tabular}

*Source: Ukrstat (2019).

** - without taking into account the areas of the temporarily occupied territories. 
The social-economic development of united communities is characterized by the interrelationship between social and economic indicators in the regions in which the respective UTCs are located. The results of the analysis have revealed the following pattern: social indicators are higher in the regions of Ukraine where economic indicators are better (Table 4-5, Fig. 1).

For instance, Dnipropetrovsk region, which ranks the 1st and the 2nd in the ranking of socialeconomic indicators (Table 5, Figure 1), has a gross regional product in 2019 of UAH 369 billion, capital investment of UAH 67 billion (18\% of GRP) (Table 4), and the disposable income per employee aged 15-70 years - 197 thousand UAH per a year. During the same period in the Chernivtsi region (rating 22-25 on various social-economic indicators) gross regional product amounted to UAH 33 billion, which is 10 times less than the Dnipropetrovsk region, capital investment - UAH 4 billion (12\% of GRP), and disposable income per employee aged 15-70 years - 111 thousand UAH per a year.

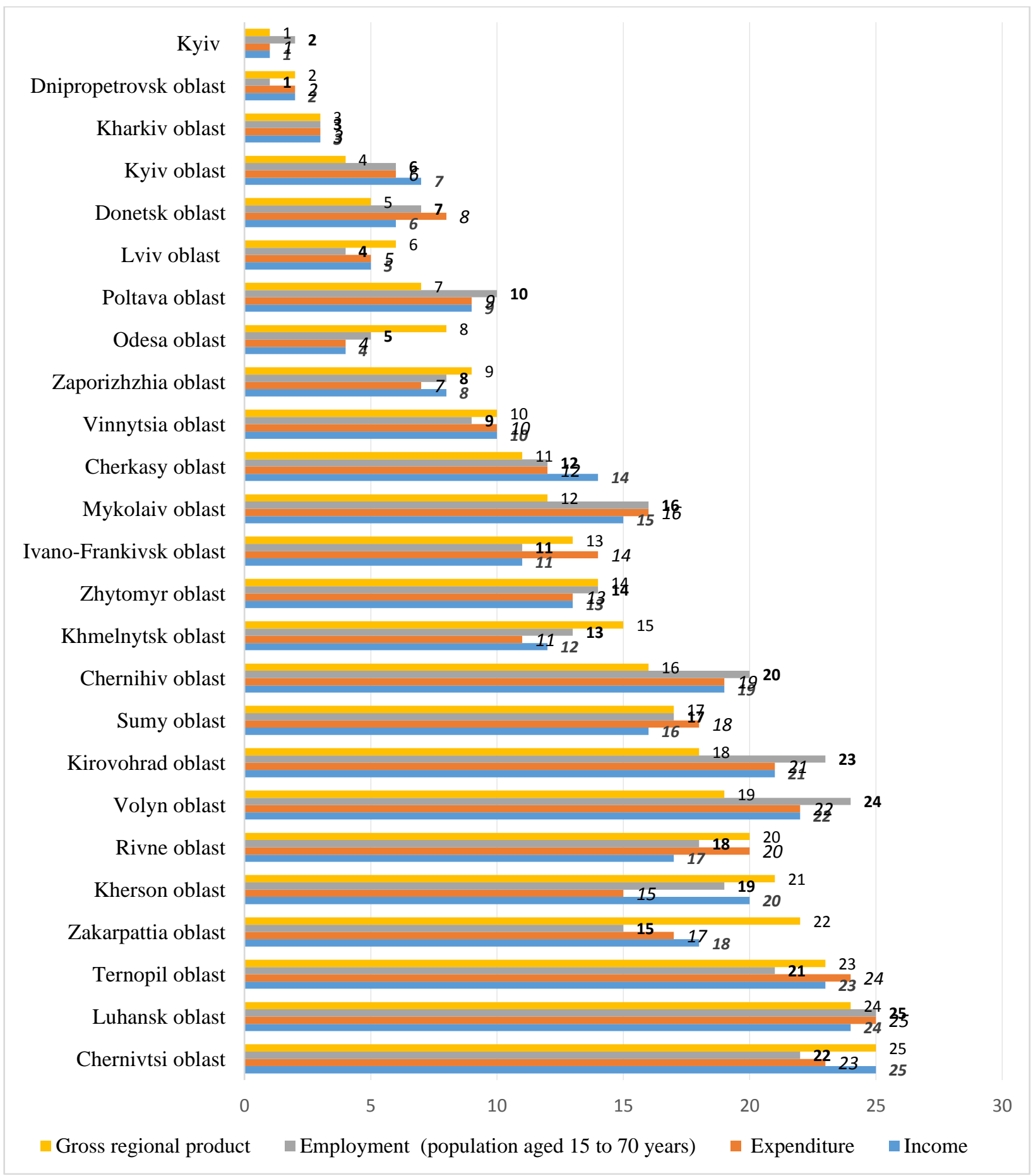


Fig. 1 Comparison of the rating of regions of Ukraine by social and economic indicators $* * *$ * Source: Ukrstat, 2019. URL: http://www.ukrstat.gov.ua/.

**rating 1 corresponds to high social-economic indicators, respectively, rating 25 - low.

Table 5. Social and economic indicators in the regions of Ukraine*

\begin{tabular}{|c|c|c|c|c|c|c|}
\hline Region ** / Rank & Income & $\begin{array}{l}\text { Disposable } \\
\text { income }\end{array}$ & Expenditures & $\begin{array}{c}\text { Employed } \\
\text { population aged 15- } \\
70 \text { years }\end{array}$ & $\begin{array}{c}\text { Capital } \\
\text { investments }\end{array}$ & $\begin{array}{l}\text { Gross regional } \\
\text { product }\end{array}$ \\
\hline Vinnytsia oblast & 10 & 9 & 10 & 9 & 9 & 10 \\
\hline Volyn oblast & 22 & 22 & 22 & 24 & 11 & 19 \\
\hline $\begin{array}{l}\text { Dnipropetrovsk } \\
\text { oblast }\end{array}$ & 2 & 2 & 2 & 1 & 2 & 2 \\
\hline Donetsk oblast & 6 & 6 & 8 & 7 & 5 & 5 \\
\hline Zhytomyr oblast & 13 & 12 & 13 & 14 & 20 & 14 \\
\hline Zakarpattia oblast & 18 & 18 & 17 & 15 & 16 & 22 \\
\hline Zaporizhzhia oblast & 8 & 8 & 7 & 8 & 10 & 9 \\
\hline $\begin{array}{l}\text { Ivano-Frankivsk } \\
\text { oblast }\end{array}$ & 11 & 11 & 14 & 11 & 17 & 13 \\
\hline Kyiv oblast & 7 & 7 & 6 & 6 & 3 & 4 \\
\hline Kirovohrad oblast & 21 & 21 & 21 & 23 & 21 & 18 \\
\hline Luhansk oblast & 24 & 23 & 25 & 25 & 25 & 24 \\
\hline Lviv oblast & 5 & 5 & 5 & 4 & 4 & 6 \\
\hline Mykolaiv oblast & 15 & 14 & 16 & 16 & 12 & 12 \\
\hline Odesa oblast & 4 & 4 & 4 & 5 & 8 & 8 \\
\hline Poltava oblast & 9 & 10 & 9 & 10 & 6 & 7 \\
\hline Rivne oblast & 17 & 17 & 20 & 18 & 23 & 20 \\
\hline Sumy oblast & 16 & 16 & 18 & 17 & 22 & 17 \\
\hline Ternopil oblast & 23 & 24 & 24 & 21 & 18 & 23 \\
\hline Kharkiv oblast & 3 & 3 & 3 & 3 & 7 & 3 \\
\hline Kherson oblast & 20 & 19 & 15 & 19 & 13 & 21 \\
\hline Khmelnytsk oblast & 12 & 13 & 11 & 13 & 15 & 15 \\
\hline Cherkasy oblast & 14 & 15 & 12 & 12 & 14 & 11 \\
\hline Chernivtsi oblast & 25 & 25 & 23 & 22 & 24 & 25 \\
\hline Chernihiv oblast & 19 & 20 & 19 & 20 & 19 & 16 \\
\hline Kyiv & 1 & 1 & 1 & 2 & 1 & 1 \\
\hline
\end{tabular}

*Source: Ukrstat (2019)

** - without taking into account the areas of the temporarily occupied territories.

The results of the analysis by using economic and statistical methods also confirm the hypothesis of the interrelationship between social and economic indicators in some regions of Ukraine (Table 6).

Table 6. Correlation matrix of social-economic indicators by regions in Ukraine *

\begin{tabular}{|l|c|c|c|c|c|c|}
\hline & Income & $\begin{array}{c}\text { Disposable } \\
\text { income }\end{array}$ & $\begin{array}{c}\text { Expendi } \\
\text { tures }\end{array}$ & Average salary & $\begin{array}{c}\text { Capital } \\
\text { investments }\end{array}$ & $\begin{array}{c}\text { Gross regional } \\
\text { product }\end{array}$ \\
\hline Income & 1 & & & & & \\
\hline $\begin{array}{l}\text { Disposable } \\
\text { income }\end{array}$ & 0,998955 & 1 & & & & \\
\hline Expenditures & 0,980336 & 0,973146 & 1 & & & \\
\hline Average salary & 0,828431 & 0,832035 & 0,776897 & 1 & & \\
\hline $\begin{array}{l}\text { Capital } \\
\text { investments }\end{array}$ & 0,942298 & 0,938928 & 0,908704 & 0,87729 & 1 & \\
\hline $\begin{array}{l}\text { Gross regional } \\
\text { product }\end{array}$ & 0,986463 & 0,983733 & 0,959985 & 0,856712 & 0,97617 & 1 \\
\hline
\end{tabular}


High indicators of gross regional product and capital investment in the regions are provided by the results of enterprises. That is, the social-economic development of the united communities is ensured by the innovation and investment activity of the enterprises on the territory of which they are located. Thus, the results of correlation analysis have identified a close interrelationship between social indicators and performance indicators of enterprises in the regions (Table 7).

Given the above mentioned, the strategy of sustainable development of UTC should include mechanisms, methods and tools to increase innovation and investment activity and improve the financial performance of its member enterprises. The UTC Sustainable Development Strategy is a long-term plan for five to ten years, which includes strategic and operational goals and mechanisms for their implementation, as well as identifies the community's development priorities in all areas of its activities. It is not a mandatory document for the operation of UTC, however, in order to attract funding for social and economic projects of the community, this document provides benefits and creates opportunities to assess areas of community development, risks and prospects for potential investors.

Table 7. Correlation interconnection between social development of UTC and performance of enterprises*

\begin{tabular}{|l|c|c|c|c|c|c|}
\hline $\begin{array}{l}\text { Social-economic } \\
\text { indicators }\end{array}$ & $\begin{array}{c}\text { Number of } \\
\text { migrants } \\
\text { (arrivals), } \\
\text { persons }\end{array}$ & $\begin{array}{c}\text { Revenues, } \\
\text { UAH million }\end{array}$ & $\begin{array}{c}\text { Disposable } \\
\text { income per } \\
\text { capita, UAH }\end{array}$ & $\begin{array}{c}\text { Expen } \\
\text { ditures, UAH } \\
\text { million }\end{array}$ & $\begin{array}{c}\text { Average } \\
\text { salary, } \\
\text { UAH }\end{array}$ & $\begin{array}{c}\text { Employed population } \\
\text { aged 15-70 years, } \\
\text { thousand people }\end{array}$ \\
\hline $\begin{array}{l}\text { Volume of sold } \\
\text { products (goods, } \\
\text { services) of enterprises, } \\
\text { UAH million }\end{array}$ & 0,67 & 0,95 & 0,92 & 0,91 & 0,87 & 0,68 \\
\hline $\begin{array}{l}\text { Number of enterprises, } \\
\text { units }\end{array}$ & 0,75 & 0,96 & 0,94 & 0,96 & 0,85 & 0,75 \\
\hline $\begin{array}{l}\text { Financial result before } \\
\text { tax of large and } \\
\text { medium-sized } \\
\text { enterprises that made a } \\
\text { profit, UAH million }\end{array}$ & 0,57 & 0,88 & 0,89 & 0,84 & 0,83 & 0,55 \\
\hline $\begin{array}{l}\text { Personnel expenses of } \\
\text { enterprises, UAH } \\
\text { million }\end{array}$ & 0,68 & 0,96 & 0,91 & 0,92 & 0,87 & 0,70 \\
\hline
\end{tabular}

*Calculated according to Ukrstat (2019)

Taking into account the social-economic indicators and performance indicators of enterprises in some regions of Ukraine, the appropriate rank for each region has been calculated and the corresponding clusters have been formed. The region with the highest social-economic indicators and performance of enterprises is assigned the highest rank 1, the next - rank 2, etc. (Table 8).

Table 8. Ranking of regions of Ukraine by indicators of social-economic development *

\begin{tabular}{|l|c|c|c|c|c|c|}
\hline Region ** / Rank & Income & $\begin{array}{c}\text { Employed } \\
\text { population } \\
\text { aged 15-70 } \\
\text { years }\end{array}$ & $\begin{array}{c}\text { Capital } \\
\text { Investments }\end{array}$ & $\begin{array}{c}\text { The volume of } \\
\text { sold products } \\
\text { (goods, } \\
\text { services) of } \\
\text { enterprises }\end{array}$ & $\begin{array}{c}\text { Financial result } \\
\text { before tax of large } \\
\text { and medium-sized } \\
\text { enterprises that } \\
\text { made a profit, } \\
\text { UAH million }\end{array}$ & $\begin{array}{c}\text { Rank, } \\
\text { average } \\
\text { value }\end{array}$ \\
\hline Kyiv & 1 & 2 & 1 & 1 & 1 & 1 \\
\hline $\begin{array}{l}\text { Dnipropetrovsk } \\
\text { oblast }\end{array}$ & 2 & 1 & 2 & 2 & 2 & 2 \\
\hline Kyiv oblast & 7 & 6 & 3 & 3 & 4 & 5 \\
\hline Lviv oblast & 5 & 4 & 4 & 5 & 9 & 5 \\
\hline Kharkiv oblast & 3 & 3 & 7 & 6 & 8 & 5 \\
\hline Donetsk oblast & 6 & 7 & 5 & 4 & 7 & 6 \\
\hline Odesa oblast & 4 & 5 & 8 & 7 & 5 & 6 \\
\hline
\end{tabular}




\begin{tabular}{|c|c|c|c|c|c|c|}
\hline Region ** / Rank & Income & $\begin{array}{c}\text { Employed } \\
\text { population } \\
\text { aged } 15-70 \\
\text { years }\end{array}$ & $\begin{array}{c}\text { Capital } \\
\text { Investments }\end{array}$ & $\begin{array}{l}\text { The volume of } \\
\text { sold products } \\
\text { (goods, } \\
\text { services) of } \\
\text { enterprises }\end{array}$ & $\begin{array}{c}\text { Financial result } \\
\text { before tax of large } \\
\text { and medium-sized } \\
\text { enterprises that } \\
\text { made a profit, } \\
\text { UAH million }\end{array}$ & $\begin{array}{c}\text { Rank, } \\
\text { average } \\
\text { value }\end{array}$ \\
\hline Poltava oblast & 9 & 10 & 6 & 9 & 3 & 7 \\
\hline $\begin{array}{l}\text { Zaporizhzhia } \\
\text { oblast }\end{array}$ & 8 & 8 & 10 & 8 & 6 & 8 \\
\hline Vinnytsia oblast & 10 & 9 & 9 & 11 & 11 & 10 \\
\hline Cherkasy oblast & 14 & 12 & 14 & 10 & 14 & 13 \\
\hline Mykolaiv oblast & 15 & 16 & 12 & 13 & 10 & 13 \\
\hline $\begin{array}{l}\text { Ivano-Frankivsk } \\
\text { oblast }\end{array}$ & 11 & 11 & 17 & 14 & 15 & 14 \\
\hline Khmelnytsk oblast & 12 & 13 & 15 & 16 & 19 & 15 \\
\hline Zhytomyr oblast & 13 & 14 & 20 & 15 & 18 & 16 \\
\hline Sumy oblast & 16 & 17 & 22 & 18 & 13 & 17 \\
\hline Kherson oblast & 20 & 19 & 13 & 20 & 16 & 18 \\
\hline Volyn oblast & 22 & 24 & 11 & 12 & 20 & 18 \\
\hline Chernihiv oblast & 19 & 20 & 19 & 19 & 12 & 18 \\
\hline Zakarpattia oblast & 18 & 15 & 16 & 23 & 22 & 19 \\
\hline Rivne oblast & 17 & 18 & 23 & 21 & 17 & 19 \\
\hline Kirovohrad oblast & 21 & 23 & 21 & 17 & 21 & 21 \\
\hline Ternopil oblast & 23 & 21 & 18 & 22 & 23 & 21 \\
\hline Chernivtsi oblast & 25 & 22 & 24 & 25 & 25 & 24 \\
\hline Luhansk oblast & 24 & 25 & 25 & 24 & 24 & 24 \\
\hline
\end{tabular}

*Source: Ukrstat (2019)

** - without taking into account the areas of the temporarily occupied territories.

The averaging of ranks by individual indicators of social-economic development has made it possible to determine the "threshold" values for each cluster: regions with a rating from 1 to 8 - have a high level of social-economic development, from 9 to 16 - medium level, 17 and less - characterized by a low level of social-economic development.

For UTCs included in the regions of the first cluster (in the city of Kyiv, Dnipropetrovsk, Kyiv, Lviv, Kharkiv, Donetsk, Odesa, Poltava and Zaporizhia regions), it is advisable to apply the adaptation strategy of sustainable development to improve innovation, investment and financial performance of enterprises. The essence of this strategy centers around achieving the optimal level of productivity, concentration of available resources in the direction of the areas that provide the greatest return. The main strategic goals in the implementation of this strategy should be aimed at the use of new forms and methods of attracting investment, development of intensive technologies, reduction of material-intensive production, etc.

For UTCs included in the regions of the second cluster (Vinnytsia, Cherkasy, Mykolayiv, IvanoFrankivsk, Khmelnytsky, Zhytomyr regions), it is advisable to apply an innovative strategy of sustainable development aimed at ensuring high competitiveness of enterprises located in the UTCs. The essence of the innovative strategy of sustainable development lies in supporting the positive dynamics of all existing indicators of enterprise activity.

For UTCs included in the regions of the third cluster (Sumy, Kherson, Volyn, Chernihiv, Zakarpattia, Rivne, Kirovohrad, Ternopil, Chernivtsi and Luhansk regions), it makes sense to follow the anti-crisis strategy of sustainable development, which is aimed at the output of enterprises located in the territory UTCs from the crisis. The implementation of the anti-crisis strategy includes strategic and operational goals, which should be aimed at optimizing costs and reducing the risks connected with instability of production, as well as the efficient use of available resources.

\section{Discussion}

The essence of the concept of "community" is based primarily on the sense of belonging, connection, communication, and interaction of people who are part of it. According to Calhoun, a community is not just a place or a population, but a large number of relationships between them [25]. These relationships involve acquaintance, social and emotional cohesion, and devotion [2]. The typology of Brint is 
one of the few that allows classifying different types of modern communities according to the following qualifications: physical interaction between members; the frequency and priorities which are given for the interaction between members; motivation to interact [3]. However, communities are recognized as not being homogeneous in social or economic indicators, because they differ in specific practices and different patterns of behavior [26].

This heterogeneity in Ukraine is caused by the unevenness of UTC associations, which is connected with a low level of their social-economic development. The obtained results confirm the development of an inertial scenario of unification of territorial communities in Ukraine, proposed by Donchenko, according to which the researcher predicts the division of communities into rich and poor, and poor communities are forced to save resources, reduce social infrastructure and rely on state support - grants and subventions [12].

In order to stimulate the capacity of UTC, it is necessary to develop its economic potential. Therefore, UTCs should develop sustainable development strategies, the main emphasis of which should be placed on stimulating investment activity, developing entrepreneurship and tourism, creating new jobs, improving infrastructure and the social sphere, which will help encourage young people and reduce the outflow of young people from UTCs. According to viewpoint of Palchuk, in Europe, for example in Poland, no institution will work with the existing Polish gmina, if it does not have a strategy for sustainable development [17].

Businesses play an important role in ensuring the social-economic development of UTCs, as they are a source of budget revenue in the form of tax payments, create new jobs, promote social development and attract investment in UTCs. The results of the analysis revealed a close interrelationship between social indicators and performance indicators of enterprises in the regions. Social-economic indicators are higher in those regions where the best performance of enterprises is observed. Therefore, the UTC development strategy should include mechanisms in order to improve the financial, innovation and investment activities of its member enterprises. The works of Buleev et al., have proven the connection between the investment activity of enterprises and the investment attractiveness of the regions that include these enterprises. It was noted that in 2017 the highest level of investment attractiveness was observed in Dnipropetrovsk, Donetsk, Kyiv, Kharkiv regions and the city of Kyiv [19]. The above mentioned correlates with the results of this study. In 2010, the top five investment-active leaders in the regions of Ukraine included the city of Kyiv, Kyiv, Dnipropetrovsk, Donetsk and Zakarpattia regions. However, the leaders in innovation in industrial enterprises are Lviv region, Zaporizhia region and Kyiv region.

The obtained results also confirm the theoretical and practical results, from which it can be concluded that the sustainable development of the territorial community is to a great extent determined by the efficiency of financial and credit relations. It depends on the level of economic development, because the main part of the community's income is formed from the tax revenues. According to viewpoints of some researchers, this can be achieved by intensifying regional investment policy [19].

\section{Conclusions}

According to the results of the conducted research, several generalized conclusions can be made:

1. It has been found that the unification of territorial communities in Ukraine was uneven. Regions with a very high level of social-economic development and a low level of social-economic development predominate. The city of Kyiv and Kyiv region significantly (several times) exceed the development of other regions and territories of Ukraine in terms of income.

2. It has been established that the uneven distribution of UTCs by income is caused by the fact that residents of territorial communities are encouraged to join more "powerful" regions, which led to uneven distribution of communities into "rich" and "poor" ones.

3. It has been substantiated that the high level of social-economic development of individual territories and communities is determined by the results of enterprises registered in their territories. Social-economic development of UTC is ensured by high performance of enterprises in which they are located.

4. The results of the analysis of the unification of territorial communities in Ukraine have been obtained, which allowed establishing the relationship between population density within one region and the number of councils united in one UTC. It has been determined that the uneven distribution of communities is due to different social-economic development of the territories, which provokes the outflow of young people to more powerful communities. The reduction of this risk is achieved by the social-economic 
development of the territories, which is provided by the strategy of sustainable development of UTC.

5. 3 regional clusters have been grouped and formed with division into: cluster 1. UTCs and territories with a high level of social-economic development; cluster 2. UTCs and territories with an average level of social-economic development; cluster 3. UTCs and territories with a low level of social-economic development.

6. It has been substantiated that the UTC development strategy should include mechanisms to improve the financial, innovation and investment activities of its member enterprises. For UTCs that are part of the first cluster, it is advisable to use an adaptation strategy for sustainable development; for UTCs of the second cluster - innovative strategy of sustainable development; for UTCs of the third cluster - anti-crisis strategy of sustainable development in the direction of improving innovation, investment and financial activities of enterprises.

Continuation of research concerning determining the impact of enterprises on the social-economic development of UTC is promising not only in scientific terms, but also in order to solve applied problems of developing a strategy for sustainable development at the level of individual UTCs in Ukraine.

\section{References:}

[1] Lieberman, M.D. Social: Why our brains are wired to connect. Crown Publishers/Random House, 2013, $384 \mathrm{p}$.

[2] Douglas, H.. Types of Community. In: Anheier H.K., Toepler S. (eds) International Encyclopedia of Civil Society. Springer, New York, NY, 2010. https://doi.org/10.1007/9780-387-93996-4_542.

[3] Brint, S. Gemeinschaft revisited: A critique and reconstruction of the community concept. Sociological Theory, 19(1), 2001, pp. 1-23.

[4] Hillery, G. Definitions of Community: Areas of Agreement. Rural Sociology, 20 (2), 1955, pp. 111-123.

[5] Brown, B., Perkins, D. D., \& Brown, G. Place attachment in a revitalizing neighborhood: Individual and block levels of analysis. Journal of Environmental Psychology, 23 (3), 2003, pp. 259-271.

[6] Zyzda, B. Selected Issues Concerning Public Tasks of the Communes in Poland and Germany. Wroclaw Review of Law, Administration \& Economics, Vol 7:1, 2017, pp. 30-40. DOI: 10.1515/wrlae-2015-0048.
[7] Bilous, Y. Analiz pokaznykiv otsinky sotsialno-ekonomichnoho rozvytku obiednanykh terytorialnykh hromad [Analysis of indicators for assessing the socio-economic development of united territorial communities]. Visnyk skhidnoukrainskoho natsionalnoho universytetu imeni Volodymyra Dalia Bulletin of the Ukrainian National University for the Name of Volodymyr Dal, 10 (240), 2017, pp. 12-17.

[8] Pron'ko, L., Lushahina, T. \& Kolesnik, T. Decentralization of public and local authorities in Ukraine Baltic Journal of Economic Studies, 2(1), 2016, pp. 96-100. https://doi.org/10.30525/2256-0742/2016-2-196-100.

[9] Pronko, L., Kolesnik, T., \& Samborska, O. (). Activities of united territorial communities as a body of local government in the conditions of power decentralization in Ukraine. Baltic Journal of Economic Studies, 4(2), 2018, pp. 184-190. https://doi.org/10.30525/22560742/2018-4-2-184-19010.

[10] Popova, I., \& Demchenko, N. (). Territorial Societies Features: European Experience. Three Seas Economic Journal, 1(1), 2020, pp. 20-27. https://doi.org/10.30525/2661-5150/2020-1-4

[11] Tymoshenko, L.M., \& Simakhova, A.O. Sotsialno-ekonomichnyi rozvytok i yoho kerovane zabezpechennia $\mathrm{v}$ umovakh innovatsiinnoi modeli suspilnoi dynamiki [Socioeconomic development and its controlled providing in innovative model of social dynamics conditions]. Mechanizm rehuliuvannia ekonomiky. - Mechanizm of Economic Regulation, 1, 2015, pp. 68-78 (in Ukrainian).

[12] Donchenko, K. Stsenarii detsentralizatsii. Shcho ochikuie OTH pislia 2020 roku [Decentralization scenarios. What awaits OTG after 2020]. Byznes Tsenzor - Business Censor. 2018, Retrieved from URL: https://biz.censor.net/resonance/3074295/stsen ar_detsentralzats_scho_ochku_otg_pslya_2020 _roku (date of issue 21.09.2020) (in Ukrainian).

[13] Dorosh, Y., Kupriyanchyk, I., \& Dorosh, A. Problems of formation and establishment of the united territorial communities boundaries: land-legal aspects. Zemleustrii, kadastr $i$ monitorynh zemel - Land management, cadastre and land monitoring, 0 (4), 2019, pp. 14-20.

doi: 
http://dx.doi.org/10.31548/zemleustriy2018.04. 02.

[14] Evtushenko, A. \& Lushahina, T. Mykolaiv region and its united territorial communities in terms of decentralization: the indicators of efficiency. Public Administration and Regional Development. 2020. Retrieved from URL:

https://pard.mk.ua/index.php/journal/article/vie w/184 (date of issue 27.09.2020). DOI: https://doi.org/10.34132/pard2020.08.03.

[15] Kocmanova A., Hornungova J., Dočaekalova M. Sustainable Corporate Performance: Interaction between Environmental, Social, Corporate Governance and Economic Indicators, Int. J. of Applied Mathematics, Computational Science and Systems Engineering, Vol. 2, 2020, pp. 113-121.

[16] Tzu-Kuang Hsu, I-Hsun Tsai, The Effect of Tourism Development on Economic Growth in Taiwan: Export Growth as Mediator, International Journal of Circuits, Systems and Signal Processing, Vol.14, 2020, pp. 435-439.

[17] Palchuk, V. Stratehiia rozvytku OTH yak putivnyk spromozhnosti hromad [OTG Development Strategy as a Community Capacity Guide]. Ukraina: podii, fakty, komentari - Ukraine: events, facts, comments, 22, 2018, pp. 45-54. Retrieved from URL: http://nbuviap.gov.ua/index.php?option=com_c ontent $\&$ view $=$ category $\&$ layout $=$ blog $\& \mathrm{id}=24 \&$ Itemid $=184$ (date of issue 16.09.2020) (in Ukrainian).

[18] Tolubyak, V. \& Kostetskyy, V. Perspektyvy rozvytku obiednanykh terytorialnykh hromad $\mathrm{v}$ Ukraini [Perspectives for the development of the unified territorial communities in Ukraine]. Investytsii: praktyka ta dosvid - Investments: practice and experience, 14, 2019, pp. 33-41 (in Ukrainian).

[19] Buleev I.P., Bryukhovetskaya N., Korytko T.Yu., Piletska S.T., Kruk O.N. Formation of a Regional Development Strategy According to the Level of Investment Activity of
Enterprises. Montenegrin Journal of Economics, Economic Laboratory for Transition Research (ELIT), vol. 15(3), 2019, pp. 113-124.

[20] Kvon G.M., Lushchik I.V., Karpenko M.A., Zaitseva N.A., Kulkov A.A., Galushkin A.A., Yakupova N.M. Regional investment policy: analysis and assessment of the investment environment state. Journal of Analytical Chemistry, 12, 2017, pp. 835 - 853.

[21] Olson, M. The Logic of Collective Action. Public Goods and the Theory of Groups. Garvard University Press, Cambridge, Massachusets and London, England, 1971, 186 p.

[22] Buchanan, J. M. An Economic Theory of Clubs. Economica. Vol. 32:125, 1965, pp. 114.

[23] Novak A., Bashtannyk V., Buryk Z., Parkhomenko-Kutsevil O., Andriyenko M. Anti-Corruption Policy under the Conditions of Overcoming the Consequences of the Coronavirus Pandemic. Systematic Reviews in Pharmacy 11(10), 2020. doi: 10.31838/srp.2020.10.136/

[24] Sysoieva, I. Balaziuk, O. and Pylypenko, L. Modelling of enterprise's accounting policy: theoretical aspect, Baltic Journal of Economic Studies, vol. 5, no. 1, 2019, pp. 188-194. https://doi.org/10.30525/2256-0742/2019-5-1188-193.

[25] Calhoun, C. Community without propinquity revisited: communications technology and the transformation of the urban public sphere. Sociological Inquiry, 68 (3), 1998, pp. 373397.

[26] Little, A. The politics of community: theory and practice. Edinburgh: Edinburgh University Press, 2002.

\section{Creative Commons Attribution License 4.0 (Attribution 4.0 International, CC BY 4.0)}

This article is published under the terms of the Creative Commons Attribution License 4.0

https://creativecommons.org/licenses/by/4.0/deed.en_US 